\title{
VISUAL MOTIFS OF AMAMZADHHAYTHE CITY OFDAMAVAND IN TEHRAN BASED ON THEMATIC DIVISION. CASE STUDY: AMAMZADGANABDOLAH AND OBAIDOLAH (AS)
}

\author{
Atieh Youzbashi \\ Master of Visual Communication, Faculty of Arts, Shahed University, Tehran, Iran \\ Email: Atiehyouzbashi@yahoo.com \\ Parviz Eghbali \\ Assistant Professor of Faculty of Art, Shahed University, Tehran city, Iran \\ Email:eghbali@shahed.ac.ir
}

\begin{abstract}
Arts used in the Holy is one of the most striking aspects of Islamic culture and spiritual atmosphere in illustrative display The method of research is based on descriptive and analytical nature and methods of data collection is used in combination (library and field). The study population is 39 Shrine scope of Awqaf administered city of Damavand in Tehran province. In the form of non-random sampling (optional) and 4 samples of the designs AmamzadganAbdolah and Obaidolah (as) Damavand and analysis of information is qualitative and quantitative. In this study, we examined the basic Articles of motifs Then, for example Shrine ofAmamzadganAbdolah and Obaidolah (AS) was introduced and designs and other features are given in the table and 4motifs was analyzedin symbolism. Distribution of relief are presented on the basis of division within Amamzadhhay ofthis city in tables and graphs . Discover the meaning of the motifsis necessary and requires a deep study about it. Due to the symbolism and motifs continuity during different historical periods was of the features and Islamic Iranian art forever. This paper attempts to Consider the characteristic image motifs, designs and examine the roots of the ideological and symbolic meanings. The results of this study show that the plant designs is the highest motifs in frequency distribution tables and charts in Amamzadhhay city of Damavand.
\end{abstract}

Keywords: visual motifs, Shrine, a symbol, a city of Damavand, Imamzadeh Abdullah and Obeydullah $(A S)$

\section{INTRODUCTION}

In Islamic lands and holy places revered by the people, always had been room for growth and talent of artists and geniuses a Muslim. "Among the different branches of architecture, mausoleum buildings hold a special place, So that the texture and were rooted Iranian culture and the mosques, the most common type of public building in Iran. "(Neiestani and Lyny, 1392: 48) Religious centers such as the holy shrines are unique treasures of Islamic art. Iranian art is rich in symbols And in the creation of art works, technical skills with a deep faith are very effective, And addressing broad concepts in forms that have long had a place in Iranian art .Emamzadeh motifs are place of manifestation thought, taste, art and people's feelings. In dealing with images and motifswas sentient and knew very well symbolic meaning of the relationship between form and function.Neverbeing merely decorative motifs and concepts were special. And in some cases also the motifs means mysticism profound and deep convictions stemming from mysticism. You can rely on their traditional values and national culture and identity then created works that showIranian 's image and identity. It is necessary to do an insight analysis into the fundamental foundation of Islamic art in Iran that is very beautiful and detailed.The idea of perfectionism of Muslim artists that stems from Islamic teachings, is an important part of survival Islamic Art. Artist seeker Allah knows all the beautiful nature as a reflection of Allah beauty. Thus, attempts to reflect the effects of it on their own artifacts. This way of thinking such as mold and the most common mental invisible links all branches of Islamic art . Theartist knows every 
plan and motifs as a means to worship and inner peace That's why by watching their work, spiritual peace is created in the spirit of the viewer. Religious buildings and shrines in various Islamic periods, has always been a breeding ground for emerging talent and creativity of Muslim artists. The architecture and decoration of its affiliate, the Islamic art became one of the main place of manifestation. And decorative motifs of Islamic art in the hands of craftsmen, was transformed asthe element of expression and sincere devotion to the dead owner of the building. (KhakbazAlvndyan and Sciences, 1391: 46). Valuation criteria in man's mind are the concept of building standards criteria and construction concepts. Countless facts and events that are beyond human understanding leads people to express ideas and concepts that are difficult to understand and verbal descriptions, invent various systems of symbols. Amamzadhhay article the importance and necessity of imagine motifs in city of Damavand Tehran Province to provide a general classification is convenient and practical. The use of semiotics science describe and interpret the imagine motifs of the novelty of this study is the most innovative technologies in the research, collect imagine motifs in religious places (Emamzadeh) in the city that hasn't be done.

\section{RESEARCH METHODOLOGY}

The research method is analytical, at first, photography was done all the motifs Amamzadhhay city of Damavand (39 e) by the method of field. Then all motifs of each the Emamzadehwas mentioned separately in the table and type of motifs based on the division motifs and other features.the Distribution results of motifs are presented in tables and charts. Then, based on of semiotics science 4 choice motifs was examined inAmamzadgan Abdullah and Obeydollah (AS) in Damavand. Data collection tools is: observation, camera (photography and videography) and scanning site, taking notes (books, articles, theses, reports), method of data collection: a combination (library, field and internet) and data analysis quantitative (statistical) and qualitative (reason, logic and reasoning). Iranian architecture, both from the Islamic period as well before have index values that are stable, most notably, the relationship between art and spiritual traditions taken from the art. The evolution of Iran's artwork, often is formed in the context of the evolution of internal conceptual artists . This feature is ideal for artists to prefer reality on simplicity and summary writing have preferred to naturalism, even in the oldest architectural monuments that have left Inscriptions. .There are decoration principles in Emamzadeh architecture that are purely Islamic and have been emerged in form of the arabesque and curves, geometrical and girih tiles, motifs inscriptions and pictographs . Types of motifs are numerous, because any archaeological search led to the discovery of a new set of motifs. Thus, Iran would study the motifs of the classification. Great scholars such as Arthur Pope during archaeological research in the book of"An Intension in Iranian art and masterpieces of art" R.W Ferreira in the book "The Art of Iran", Zaki Mohammad Hasan in his book "The Art of the Islamic era" and Drek Hill and Oleg Grabar in the book "Islamic architectural decorations", to classify motifs, Most of the four main groups that are related to the subject of this study According the same thing in the present study, Types of motifs used in Emamzadeh will explain in terms of imagine in four categories and each individually. But human motifs not used because the Emamzadeh is not mentioned in the table and motifs pictographs added to this classification.

\section{HISTORY RESEARCH}

In connection with architectural motifs in Damavand city Amamzadhhay little research has been done. The following studies have been done on decorative motifs:

1. Purmand, H. (1385), "geometry, Islamic architecture and decorative motifs (scroll Tvpqayy)", the magazine Art Monthly, 91 and 92, pp. 20-24.Topkapi scroll is a set of paintings for brickwork and tiles as well as design and MogharnasRsmybndy, and an extensive discussion on the historical and theoretical geometry and architecture's role and decorations. Topkapi scroll set of paintings for brickwork and tiles as well as design and traditional, Formal, and an extensive discussion on the historical and theoretical geometry and architecture's role and decorations. 
2. Sarikhani, Majid; Sharifinia, Akbar and Ahmed, A. (1394), "Analysis of Iranian-Islamic motifs Gchbryhay Shrine Abdullah (AS) Arak", the history of Islamic culture and civilization, 18, pp 155176This paper marks the foundation of the decorative motifs, influenced by the Sassanid era stucco and content sources as it is influenced by the teachings of the divine and important social events,Four changed human and animal motifs and therefore, tends to be abstract and taking a look at the mythology of their plant designs, the use of geometric designs and delivers inscription can be seen in the context of the shrine stucco motifs.

3. Saeedi, S. (1380), "an expression of the Islamic geometric patterns - Iran". Master thesis, Islamic Azad University of Tehran.visualrelationship.goal of this thesis is cultural and artistic community awareness today of the traditional arts, especially geometric patterns rooted in the culture, religion and beliefs of past periods. And in comparison with other arts is neglected in defining and understanding . It hope that by understanding the content and meaning, the real values give it more prosperous. The research design: four main chapters covers the first and second types are applied that mainly include history, philosophy and science concepts. And the third kind of spiritual is concepts and fitness covers and the end is discussed the geometric shapes and patterns.

4. Shekaryneiry, Jold, (1385). "theoretical mysticism and Applied Arts motifs in Islamic architecture", the magazine Art Monthly, 91 and 92, pp. 8 - 19. author's state of the art and geometry to explain mysticism, Shamse and Shms.hgrdan designs, materials and knots line four single bergamot has a role.

5. Ghamari, F. (1392), light and motif, First Edition, Tehran, Culture and Communication. In this study, a comparative study of the art of illumination and traditional poem five synthetic art to convey contemporary concepts of Islamic Sufism.

6-Keshavarzi, M. (1380), geometry designs, MehrdadAhmadiSheikhan, First Edition, Tehran, culture Sba.nvysndgan the symbols and myths, draw geometric shapes, geometric shapes Open, Open forms and roles in Iran's and motifs on the subject, has classified in schematic form.

7. Nadim, F. (1386). "Take the decorative motifs in Iranian art". Journal of Art Education, 10, pp. 14 19.writer delivered different categories of books focused: on the Style of play,, based on the style of expanding the role based on the role.

Imamzadeh Abdullah Obeydullah (AS) Damavand

"The Shrine of buildings in Damavand is very late 7th century AH. The building of tower Monument is a shrine with ridged body (and the images are painted on the teeth) and the color turquoise dome That the outer surface, the plaster seals can be seen. There is an inscription containing verses in the Holy Quran. " (Http://rclit.ir/Default.aspx?tabid=598 ) This monument are 550 meters north of Damavand and in the neighborhood Darwishnear the central Mosque is located. (Najafi, 1390: 135)

Table 1.Overview of the ImamzadehAbdollahObeydullah (AS) Damavand. Source: authors)

\begin{tabular}{|l|l|}
\hline Emamzadeh Abdullah Obeidullah (AS) Damavand & $\begin{array}{l}\text { Emamzadeh } \\
\text { Name }\end{array}$ \\
\hline Damavand, neighborhood DarwishDarwish neighborhood near religious site & Place \\
\hline Late Seljuk period and the patriarch (7th century AD) & $\begin{array}{l}\text { Period } \\
\text { back) }\end{array}$ \\
\hline Plaster & Building interior \\
\hline Tile, Brick & Building Exterior \\
\hline Through the skullcap, plasterFrom the outside with tiles & Roofing materials \\
\hline Mosaic & $\begin{array}{l}\text { Flooring material } \\
\text { monument }\end{array}$ \\
\hline
\end{tabular}




\begin{tabular}{|l|l|}
\hline Cone Rack & Type Dome \\
\hline Doesn't have & Finial \\
\hline 2 miracles inlaid windows & shrine \\
\hline 7 windows6 windows in the roof & window \\
\hline $\begin{array}{l}4 ; 1 \text { main entrance, } 2 \text { at the entrance of the shrine; } \\
1 \text { at the entrance to the courtyard }\end{array}$ & door \\
\hline
\end{tabular}

"The building of brick tower, outside the circular stairs, has 33 edge that starts from the base The interesting thingis about Chinese brick tower that has a height of three meters decorations, and from this height, the typical Chinese brick is started. Decorations between the bricks, pieces of plaster that vertical bands filled the bricks. (Habibi, 1389: 190) In view of the building under the dome with plaster Shms hay have created roles, Shamse located in the midst of all the involved stars such, This role is highlighted In the center of the star motif, the role created Shamse, then repeat the same until the stars come out. They will take all the stars on each tip of the triangle, there diamond. Among them appeared to highlight the role of decorative petals. 4 of the diamond has been lost All roles are petals decorative moldings that prominently shown. This shrine has geometric designs, plants, animals, and ispictographs. (Table 1 and Table 2)

Table2. Total motifs ImamzadehAbdollahObeydollah (AS) of Damavand. Source: authors

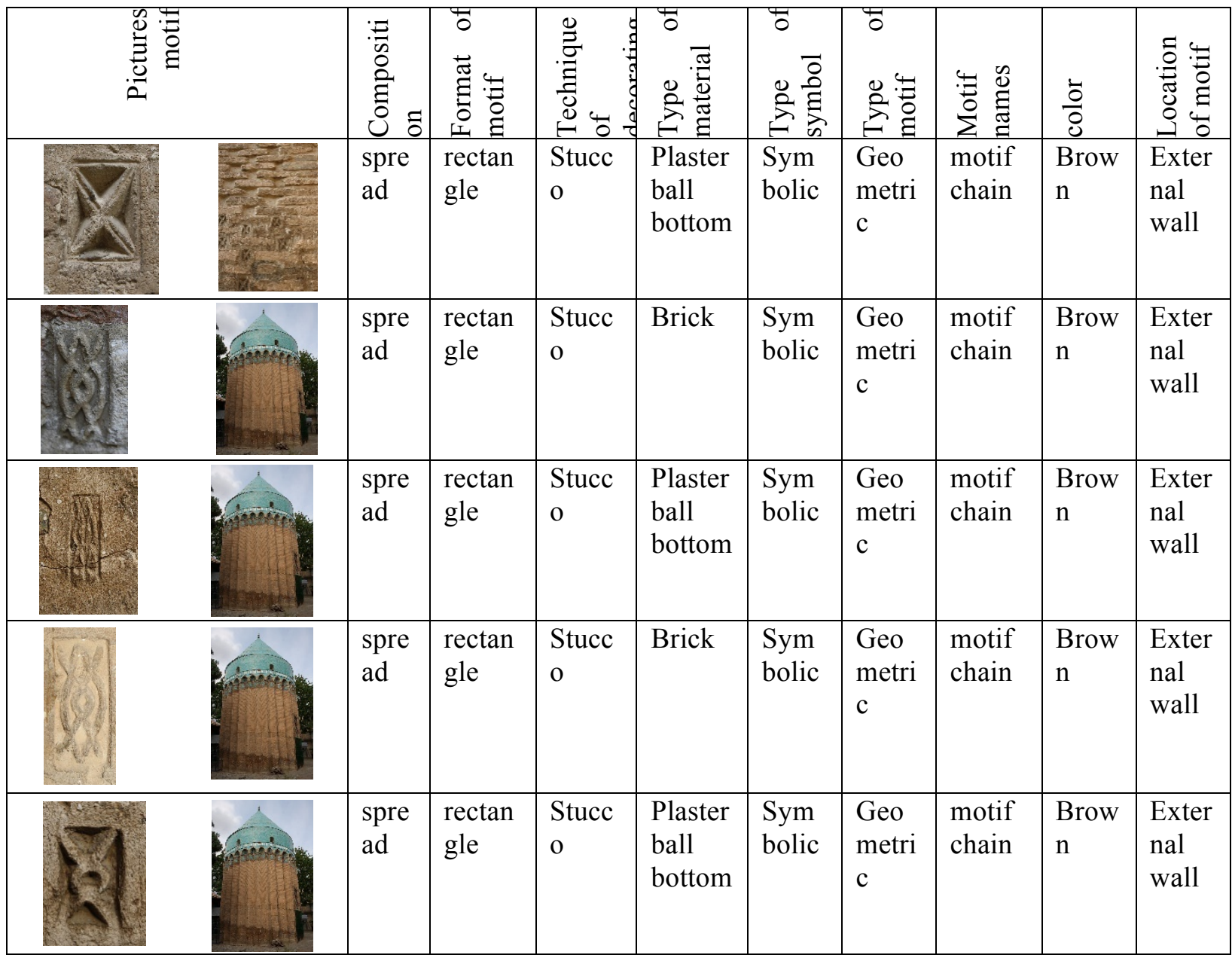




\begin{tabular}{|c|c|c|c|c|c|c|c|c|c|}
\hline करs? & $\begin{array}{l}\text { Hori } \\
\text { zont } \\
\text { al }\end{array}$ & $\begin{array}{l}\text { Diam } \\
\text { ond }\end{array}$ & $\begin{array}{l}\text { Wood } \\
\text { carvin } \\
\mathrm{g}\end{array}$ & Wood & $\begin{array}{l}\text { Sym } \\
\text { bolic }\end{array}$ & $\begin{array}{l}\text { Geo } \\
\text { metri } \\
\text { c }\end{array}$ & Eslimi & $\begin{array}{l}\text { Brow } \\
n\end{array}$ & door \\
\hline & $\begin{array}{l}\text { Hori } \\
\text { zont } \\
\text { al }\end{array}$ & $\begin{array}{l}\text { Diam } \\
\text { ond }\end{array}$ & $\begin{array}{l}\text { Wood } \\
\text { carvin } \\
\mathrm{g}\end{array}$ & Wood & $\begin{array}{l}\text { Sym } \\
\text { bolic }\end{array}$ & $\begin{array}{l}\text { Geo } \\
\text { metri } \\
\text { c }\end{array}$ & $\begin{array}{l}\text { Decor } \\
\text { ative }\end{array}$ & $\begin{array}{l}\text { Brow } \\
n\end{array}$ & door \\
\hline 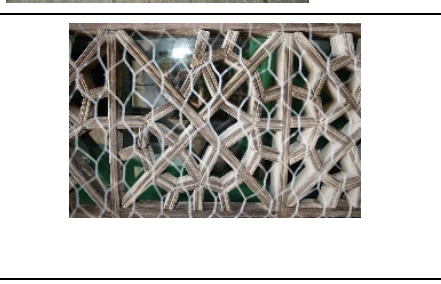 & $\begin{array}{l}\text { spre } \\
\text { ad }\end{array}$ & $\begin{array}{l}\text { Diam } \\
\text { ond }\end{array}$ & $\begin{array}{l}\text { Lattic } \\
\text { ed } \\
\text { wood } \\
\text { en } \\
\text { Orsis } \\
\text { azi }\end{array}$ & Wood & $\begin{array}{l}\text { Sym } \\
\text { bolic }\end{array}$ & $\begin{array}{l}\text { Geo } \\
\text { metri } \\
\text { c }\end{array}$ & $\begin{array}{l}\text { Decor } \\
\text { ative }\end{array}$ & $\begin{array}{l}\text { Brow } \\
n\end{array}$ & $\begin{array}{l}\text { shrin } \\
\text { e }\end{array}$ \\
\hline Dह 80 & $\begin{array}{l}\text { Sym } \\
\text { metr } \\
\text { y }\end{array}$ & Circle & $\begin{array}{l}\text { Gildi } \\
\text { ng on } \\
\text { plaste } \\
\mathrm{r}\end{array}$ & $\begin{array}{l}\text { Paint } \\
\text { on } \\
\text { plaster }\end{array}$ & $\begin{array}{l}\text { Sym } \\
\text { bolic }\end{array}$ & Plant & $\begin{array}{l}\text { Gildin } \\
\mathrm{g}\end{array}$ & $\begin{array}{l}\text { Tradi } \\
\text { tional } \\
\text { color } \\
\mathrm{s}\end{array}$ & roof \\
\hline & $\begin{array}{l}\text { Sym } \\
\text { metr } \\
\text { y }\end{array}$ & $\begin{array}{l}\text { Squar } \\
\mathrm{e}\end{array}$ & $\begin{array}{l}\text { Etchi } \\
\text { ng }\end{array}$ & Metal & $\begin{array}{l}\text { Iconi } \\
\text { c }\end{array}$ & $\begin{array}{l}\text { Anim } \\
\text { al }\end{array}$ & Eagle & $\begin{array}{l}\text { Blac } \\
\mathrm{k}\end{array}$ & Door \\
\hline & $\begin{array}{l}\text { Sym } \\
\text { metr } \\
\text { y }\end{array}$ & $\begin{array}{l}\text { rectan } \\
\text { gle }\end{array}$ & $\begin{array}{l}\text { Etchi } \\
\text { ng }\end{array}$ & Metal & $\begin{array}{l}\text { Iconi } \\
\text { c }\end{array}$ & Plant & $\begin{array}{l}\text { Flowe } \\
\mathrm{r}\end{array}$ & $\begin{array}{l}\text { Blac } \\
\mathrm{k}\end{array}$ & Door \\
\hline & $\begin{array}{l}\text { Hori } \\
\text { zont } \\
\text { al }\end{array}$ & $\begin{array}{l}\text { triangl } \\
\mathrm{e}\end{array}$ & $\begin{array}{l}\text { Gildi } \\
\text { ng }\end{array}$ & tile & $\begin{array}{l}\text { Sym } \\
\text { bolic }\end{array}$ & Plant & $\begin{array}{l}\text { Decor } \\
\text { ative }\end{array}$ & $\begin{array}{l}\text { Blue } \\
\text { cyan } \\
\text { Whit } \\
\text { e }\end{array}$ & $\begin{array}{l}\text { Exter } \\
\text { nal } \\
\text { wall }\end{array}$ \\
\hline & $\begin{array}{l}\text { Hori } \\
\text { zont } \\
\text { al }\end{array}$ & $\begin{array}{l}\text { rectan } \\
\text { gle }\end{array}$ & Burl & Wood & $\begin{array}{l}\text { Sym } \\
\text { bolic }\end{array}$ & $\begin{array}{l}\text { Picto } \\
\text { graph } \\
\mathrm{s}\end{array}$ & Eslimi & $\begin{array}{l}\text { Gold } \\
\text { en }\end{array}$ & $\begin{array}{l}\text { Crow } \\
\text { n } \\
\text { Shrin } \\
\text { e }\end{array}$ \\
\hline & $\begin{array}{l}\text { Hori } \\
\text { zont } \\
\text { al }\end{array}$ & $\begin{array}{l}\text { rectan } \\
\text { gle }\end{array}$ & $\begin{array}{l}\text { Carve } \\
\mathrm{d} \\
\text { wood, } \\
\text { enam } \\
\text { el }\end{array}$ & Wood & $\begin{array}{l}\text { Sym } \\
\text { bolic }\end{array}$ & $\begin{array}{l}\text { Picto } \\
\text { graph } \\
\mathrm{s}\end{array}$ & $\begin{array}{l}\text { Frame } \\
\text { d } \\
\text { Quran } \\
\text { ic } \\
\text { inscri } \\
\text { ption }\end{array}$ & $\begin{array}{l}\text { Brow } \\
n\end{array}$ & $\begin{array}{l}\text { Dow } \\
\mathrm{n} \\
\text { crow } \\
\mathrm{n} \\
\text { shrin } \\
\mathrm{e}\end{array}$ \\
\hline Decentralized & $\begin{array}{l}\text { Dec } \\
\text { entr } \\
\text { aliz } \\
\text { ed }\end{array}$ & Circle & $\begin{array}{l}\text { Wood } \\
\text { carvin } \\
\mathrm{g}\end{array}$ & Wood & $\begin{array}{l}\text { Sym } \\
\text { bolic }\end{array}$ & Plant & Eslimi & $\begin{array}{l}\text { Brow } \\
n\end{array}$ & $\begin{array}{l}\text { Crow } \\
\mathrm{n} \\
\text { Shrin } \\
\mathrm{e}\end{array}$ \\
\hline
\end{tabular}




\begin{tabular}{|l|l|l|l|l|l|l|l|l|l|}
\hline & $\begin{array}{l}\text { Sym } \\
\text { metr } \\
\mathrm{y}\end{array}$ & $\begin{array}{l}\text { triangl } \\
\mathrm{e}\end{array}$ & $\begin{array}{l}\text { Wood } \\
\text { carvin } \\
\mathrm{g}\end{array}$ & Wood & $\begin{array}{l}\text { Sym } \\
\text { bolic }\end{array}$ & $\begin{array}{l}\text { Geo } \\
\text { metri } \\
\mathrm{c}\end{array}$ & $\begin{array}{l}\text { Repea } \\
\mathrm{t} \\
\text { triangl } \\
\mathrm{e}\end{array}$ & $\begin{array}{l}\text { Brow } \\
\mathrm{n}\end{array}$ & $\begin{array}{l}\text { Crow } \\
\mathrm{n} \\
\text { Shrin } \\
\mathrm{e}\end{array}$ \\
\hline
\end{tabular}

\section{PLACE OF THE SYMBOLS IN ISLAMIC ART}

From the mysticsism perspective, the world based on God's divinity and divine aspects of the material world. The cosmological principle has caused the entire cosmos, manifestation and expression of absolute truth. According to Plotinus, the universe is tangible manifestation of the universe. (Gilani, 1393: 67) Each of the motifs have their symbols. "The Symbolism of the word is sign, sign, encrypt and sign and terminology, practice or art of the use of symbols, principles of using symbols and signs to express the opinion or an event reminder." ". (Gilani, 1393: 23) Therefore, only by recognizing the principles metaphysical symbols and sacred sciences that finds as well as awareness of the meaning of symbols, semiotics and literature .It isunderstandable and with a mastery of comparative literature and discussions nations can be shared spirit symbols in the civilizations that have internal unity, reread. (Coomaraswamy, 1977: 330 )Symbols facilitate convey meaning can understand a sense of the complexity and difficulty simply and setup a symbol audience. (Schuon, 1963: 180) "The purpose of sacred art, not merely convey emotions and feelings, but also make the heaven and the divine, Which by using symbolism and allegory, the soul from the material world flight, the release of material limitations and understand the facts is superior. Hence, sacred art with careful use of allegory and symbol, beyond aesthetics, are used to tell the truth and ritual acts. Religious art (sacred art) often ignores the visual appeal andThe beauty of it is, more than anything of spiritual truth and, therefore, the accuracy of Coded and allegorical aspects, as well as the benefits it comes to ritual acts and mystical vision. "(Gilani, 1393: 73 and 74)

\section{MOTIF DIVIDED BY SUBJECT}

"Each motif or image means for visual image That is in the way and iconic imagery puts in the mind of humans. Image is a French word that means the statue, statues, pictures, sculptures and has been translated and all of these cases is rooted in visual arts. Volume and image is intended in them. This means that once a man uses a word for a meaning and says "snake" and once against this wordshows the picture and paintings of snake to others that this picture is said motif or image. For example, the decorative motifs of Islamic art motifs inscription is sometimes referred to tiling In which, the Quran or Hadith the third line is written and then used vegetable or animal motifs That is against relief inscription Therefore, any plant or animal motifs in Islamic culture that pays image for animals or plants, is said motif or image. " (Gilani, 1393: 22 and 23)

"Muslim architects with elements such as replication, replication, mirroring and continuous composition of motifs and geometric designs, plants, decorations and presents strong trend and have tried grandeur of the architecture with the beauty and elegance intermingle." (Dalu Jones: 161)

Amamzadhhay motifs city of Damavand in Tehran province is divided 4 categories: 1) plant designs 2) geometric 3) animal motifs 4) pictographs.

\section{THE PLANT DESIGNS.}

Eslimi designs devoted to Islam is composed of two elements: design interwoven and Vegetable designs. The interwoven designs are fundamentally interwoven graph geometric thinking. While outlining designs sign vegetable weight. And because of the spiral composition forms have perhaps received less than a real plant to a purely linear style.Eslimi designs with the loss of all their similarities have solely pursuant to the laws of nature and the rhythm weight, Eslimi designs are logical and harmonious and based on mathematical records and music melody data. "More Khtayyfeatures in the form of leaves or buttercups or pomegranate flower-inspired blue and red 
flowers. And the overall picture is generally round or oval, but across the surface decorated with arabesque movement and stillness leads. The audience glance may not stick anywhere and everywhere in the course of margin into the designs and the inside out. " (Hzavhay, 1363: 91) "Eslimi is a technique of decorating the surface or in the field of applied arts or crafts and painting) And in which form intertwined bud and flower and foliage plants that are mentioned in Islamic books ,And called the name of paradise plants used for plants such as pomegranatesDate - Grapes - Pomegranate. As a result of the initiative and imagination of several generations of artists over the centuries have shaped the world in different nations, And they have become abstract shapes or abstract. "Hzavhay, 1363: 91) on the face and appearance Slim survey stays in the circle bent headand surrender.There are several elements in Eslimi collection: (1) Paisley (Art); (2) the Eslimi; 3. grip and knots; 4 show. (Pvrkhrmy, 1383: 1)

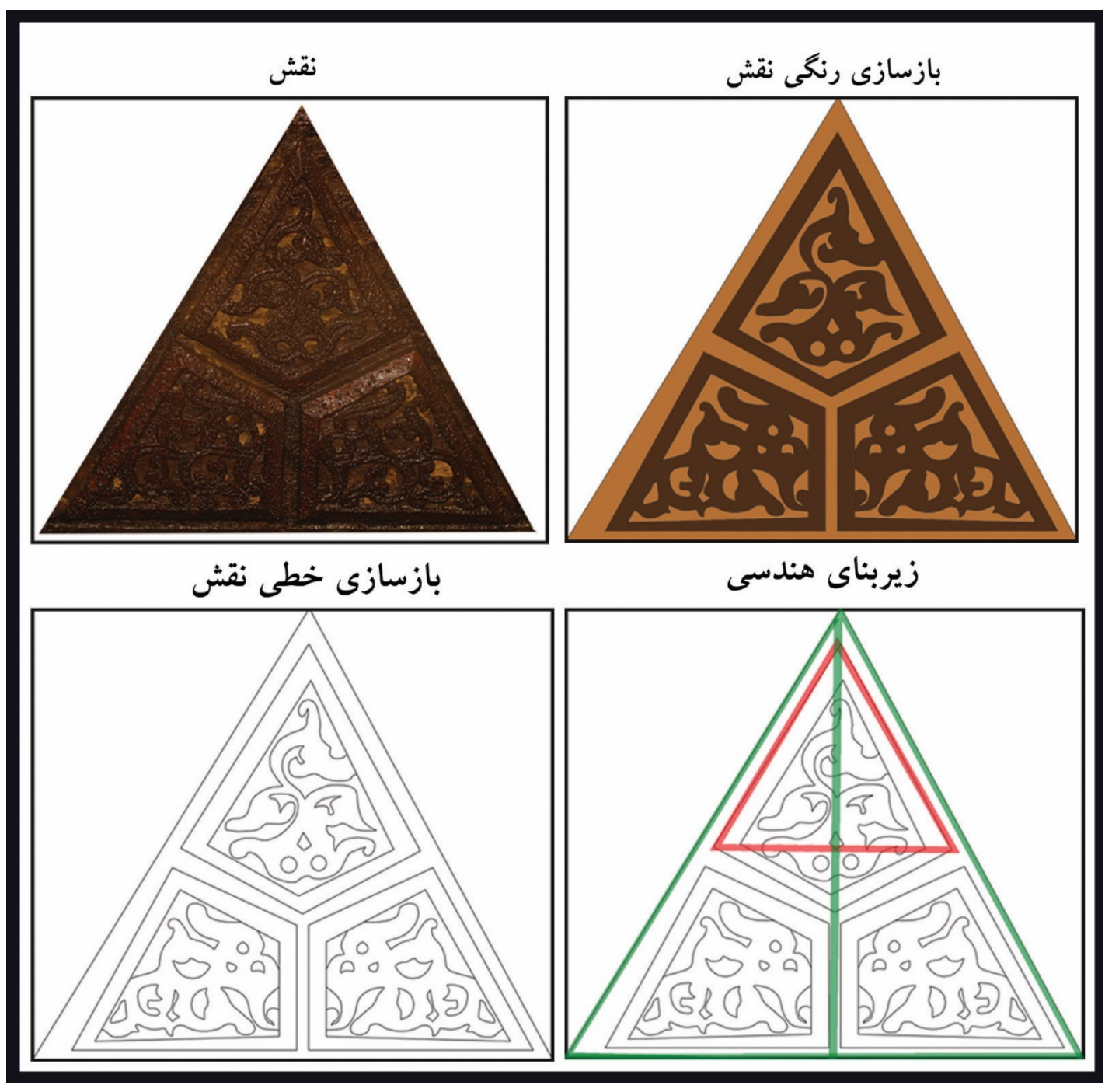

Figure1-. Holy shrine of Abdullah Obeiydullah (AS) Damavand, reconstruction and infrastructure of linear and geometric color,Source: authors

Figure 1: color reconstruction relief role

Motif Geometric infrastructure

Linear reconstruction role

The arabesque(Eslimi) motifs is seen on the shrine inlaid. Thismotif is in 3equal part of a triangle (spicy bergamot nodes) and is used brown and designed in the role of symmetrical composition. And the composition is released in the entire building. (Table 2, Figure 1) and Arabesque motifs have the 
idea of centralization to complete in their own way. Eslimili such as spiral in nature, are complex spiral that revolves around a central point. And leading to fit close to the center are narrow and thinner. Despite the lack of symmetry in that, because of the coordination, spiral has significant emotional and dynamic motion by moving towards the center The fine print expand at all levels . Figurative geometric designs of Divine Light is emitted along the same angles and present projects carried out in all points. Coordination available in various designs, there is nothing but the same sense of unity and multiplicity available. (Http://ehonari.blogfa.com/1392/07)

Girih tiles set of primitives that with discipline and bolts harmonious and symmetrical forms are arranged side by side. (Www.irandeserts.com) And the geometry of the universe is an expression of the order) An echo of unity expand within the shade. The base of pyramid is triangle. Equilateral triangle is the symbol of divinity, harmony and proportion

\section{GEOMETRIC PATTERNS}

Geometry is a knowledge that explores various forms and characteristics of each, alone or in deal with the relationship between them. This knowledge, along with the "Account" are considered of the oldest branches of "mathematics". The word geometry is an Arabic eual for Farsi version of the word "size". Geometry is coming from the Greek "Gyvmtrya" means "measuring the earth". The Mesopotamians and the Egyptians considered the first family that benefited from geometry. Until that the Egyptians were able to solve the Unknown problem of agricultural land afterthe flooding of the Nile each year. And then make it possible even to build complex structures such as the pyramids. Producing mesmerizing shapes and discover its secrets, encouraged engineers (those who know geometry) Not only in the construction of magnificent monuments but although decorate them by use of their geometry. This is especially Islamic countries that respect human and animal imagery there was more depth and destruction foundAnd became one of the distinctive features of Islamic art. Thus, geometric shapes such as circle, triangle, square, stars and polygons, combined together into a role for decorating buildings that were deployed on the same knowledge. This forms can be seen in the most Iranian art works, including architectural decorations, including tiling, girih tiles, moldings, mirror working, Mogharnas, brickwork, as well as in traditional arts such as metalworking, Mshbkkary, weavers and old wooden windows are seen in abundance. " (Agriculture and AhmadiSheikhan, 1389: $9,10)$

Islamic geometric patterns, with visual and symbolic meanings, can be used as an element with a particular cultural and traditional identity of this land, the lives of these people become irretrievably) .Geometric patterns in traditional Iranian art had a deep and unbroken link with theoretical principles, philosophy and their true origin of the religion of Islam and it was important to reflect Islamic philosophy. (Snacks Myrfkhrayy, 1393: 9) More geometric patterns are based on Islamic art and architecture, the repetition of a single motif are based.

The designs should be designed in such a way that the possibility of a link between all the components of a good repeating is possible. (Brugge, 1391: 10) Humans have always believed that everything in the world, his eternal symbol and duplicate samples in the realm of the sublime. According to this belief, a person is considered a manifestation of creation and expression and the right to the attributes of God activities. And since human beings are not all in a single level spiritual, need the same language. This common language, the same symbolic language is based on the foundations of Islamic and Iranian traditions, the esoteric facts in deal with in the case. (Snacks and Myrfkhrayy, 1393: 12).

Proportionality between the components and the total combined figures due to limitations role models and practices specific measures flows. Thus, access to a whole vast world of Islam in the Islamic faith on the basis that all creation are coordinated andconsistent, is compatible. (Said, 1392: 13). Almost geometric motifs are seen in most the existing buildings in the city of Damavand. These motifs are similar to Islamic religious motifs keep structural tissue sites such as mosques (the designs in tile, stucco, etc. are) course in this area motifs local materials like clay, wood creator have special geometric forms. (Table 2). 

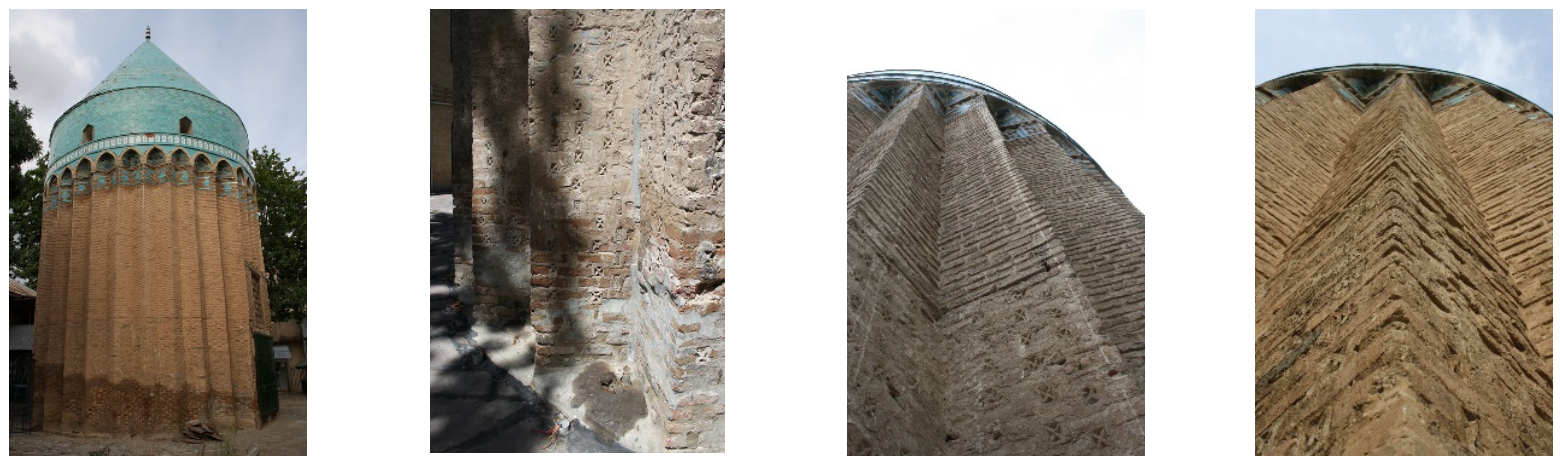

Figure 2. The outer wall of the shrine of Abdullah Obeidullah (AS) Damavand, decorative motifs; Source: authors

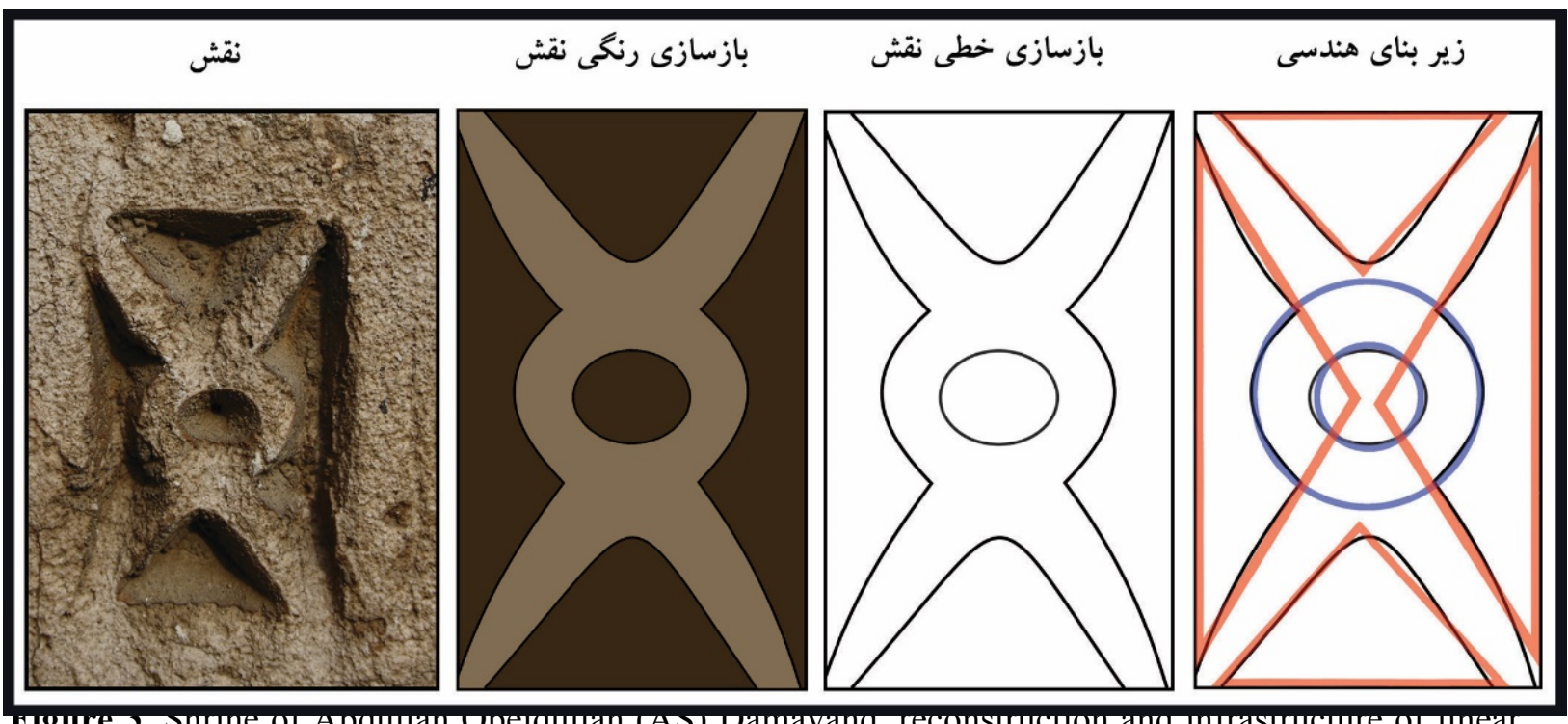

Figure 5. Snmme or Aoduman Ooerauman (AS) Damavand, reconstruction and inmastructure or mineal and

geometric color; Source: authors

Figure 1: The foundations of geometric

linear reconstruction

Color reconstruction motif

Motif 


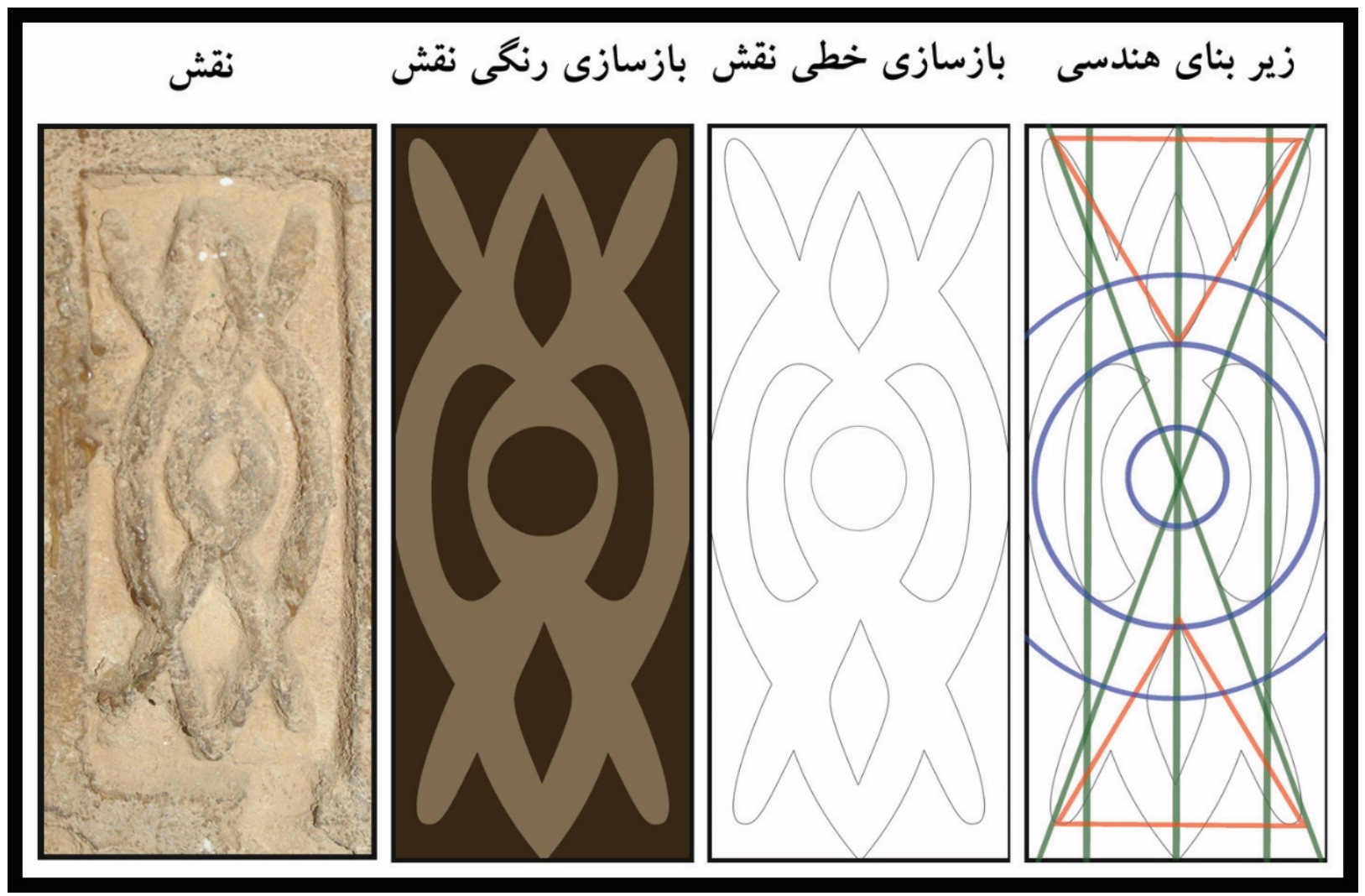

Figure 4. The outer wall of the shrine of AbdullahObeidullah ... Damavand (AS), reconstruction of infrastructure and the role of linear and geometric color;

Source: authors

Figure 1: The foundations of geometric

Linear reconstruction

Color reconstruction motif

Motif

This decorative chain in the form of a rectangle is drawn. (Figure 1, Figure 2 and Figure 3), Forms to a considerable degree summarized and used to draw these forms of 4 isosceles triangle is 2 to 2 are the same size. And symmetrically opposite the circular table is in the center of motif in everyone's role. Artists are successful in drawing the designs on the plaster. Designed in the role of symmetrical composition is used and the composition is released in the entire building. (Table 2) A special kind of decorative motifs used in buildings and patriarch of the Seljuk period, that it is tasteful and architects is uniform to bring out the interest of the state,This role is often used often in the shape plaster and concrete and how to implement it, are the same in almost every patriarch and Seljuk buildings. However, according to the article "The doctor A. Dadvar" Donald Wilbur has chosen. "bottom brick plaster hub" for the decoration of choice that at first glance appear unfamiliar words. (RADVAR, 1385: 92) This type of decoration can be seen in many buildings as it seems.At First, for the same chain designs on the wall were run and later more fully with Kofi lines and ornamental plants in combined. However, according to some guiding this sign means "day" But it seems was used inIlkhani era more especially as a seal architects. The main role of the center as a rule, be expanded to other areas. Although this type of decoration in its evolutionwas more complex and more perfect,but over time their application was reduced gradually. And the main reason for this issue was the entrance of tile , particular tile seven colors as a quick ornamental tool in architecture. This role not only in the Holy Abdullah Obeidullah (AS) Damavand, but in most places where the "plaster finish bottom of the 
brick" used, has gone as a key part of the work . Including: Grand Mosque of Yazd, Isfahan Grand Mosque and Grand Mosque of Saveh.Khampaare those types of decorative chains that have been created only by the combination of visual elements "line". They are decorations thathas been created Specifically from the motion or tangled twist of a line (a line forms) in a ball space. Find coils along the horizontal grouting ball into space, its movement within this space, and entangled it in this space, iscreated a kind of decorative chain . The most well induce a sense of movement. (Dadvar, 1385: 91) Artist designs are simple and well in pulling the plaster on the Astlyz $\mathrm{h}$.The symmetrical composition is used in designing the role and this composition is spread in the entire building. Religious opposition to decorate the image of Muslims with any aspect of idolatry that was a cause extreme attention to decorations were abstract and geometric. (Hylnbrand, 1378: 168). All roles camera observed what looked like a brick or stone bottom EmamzadehObeidullah Abdullah (AS), are geometric patterns. Geometric patterns have been used on the hub to have specific and detailed visual. In all these roles to avoid the diversity and distribution, as only using one of two basic elements are formed such as lines and triangles, lines and circles, squares and triangles . Observance of the principle of repetition and symmetry with the development of rhythm, movement coordination is varied in relationships between elements of the cause massive motifs. Cosmetic function is decorative and architectural aspects of values and a building with all components and units isthought as a whole, interconnected and coordinated. No other components does not present any details if possible. This kind of thinking in the construction of sacred buildings such as mosques can be built, particularly in centrifugal spiritual approach to the entire community and origin of creation be considered. (Dadvar, 1385: 91)

\section{THE ANIMAL MOTIFS}

Restrictions of Muslim religious beliefs caused not to extend this relief. In general, the scope of these designs is very limited. Animals have always had a special place in the culture andbelieve of Persians. And the use of animal motifs for writing short is the defining characteristic of Iranian art. Throughout history, artists of various disciplines from have used the shape of animals under their creations to their advantage. In this context, is not like the Iranian nation's. Iranians have had different ideas and beliefs about animals, because he has been drawing these designs on a variety of hand-made. The same opinions are that give profound implications to their works. Imagining Islamic tradition continued during treatment with animal motifs in a variety of industries and applied arts. Numerous examples of this image could be seen. the remnants of different ages. That images which have been recreated carefully, with attention to detail and exquisite abstract manner. (Nadim, 1386: 10)
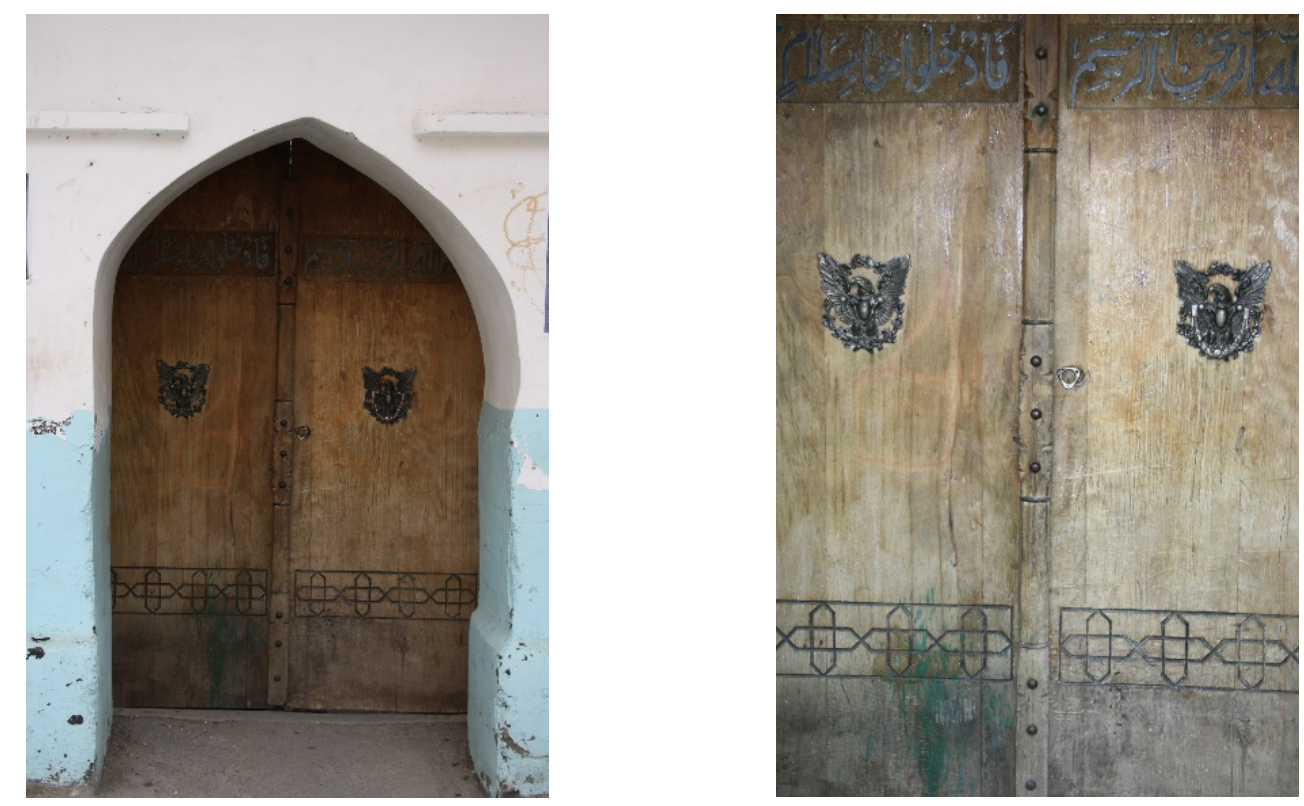

Figure 5. The role of the Holy Abdullah Obeidullah (AS) Damavand, the eagle; Source: authors 
The eagle'swings is seen that it is open to the top And the eagle look on every door on the left. Inside a ring of flowers and plants has opened its wings. (Table 2, Figure 5 and Figure 6) Traditionally Eagle, among the various nations, was and is as a symbol of authority based on insight. "Eagle", as the strongest flying creatures, is not only a symbol of authority in heaven and on earth but also because of the prospect of an unattainable place (heaven), is also a symbol of insight. Sign of "Eagle" among the Aryans was been as one of the most prestigious and most respected symbols of mythological purported.Extent that at the time of "Cyrus the Great" and by his command, has become a national symbol Corp and the fact sign of the authority of the Persian Empire.

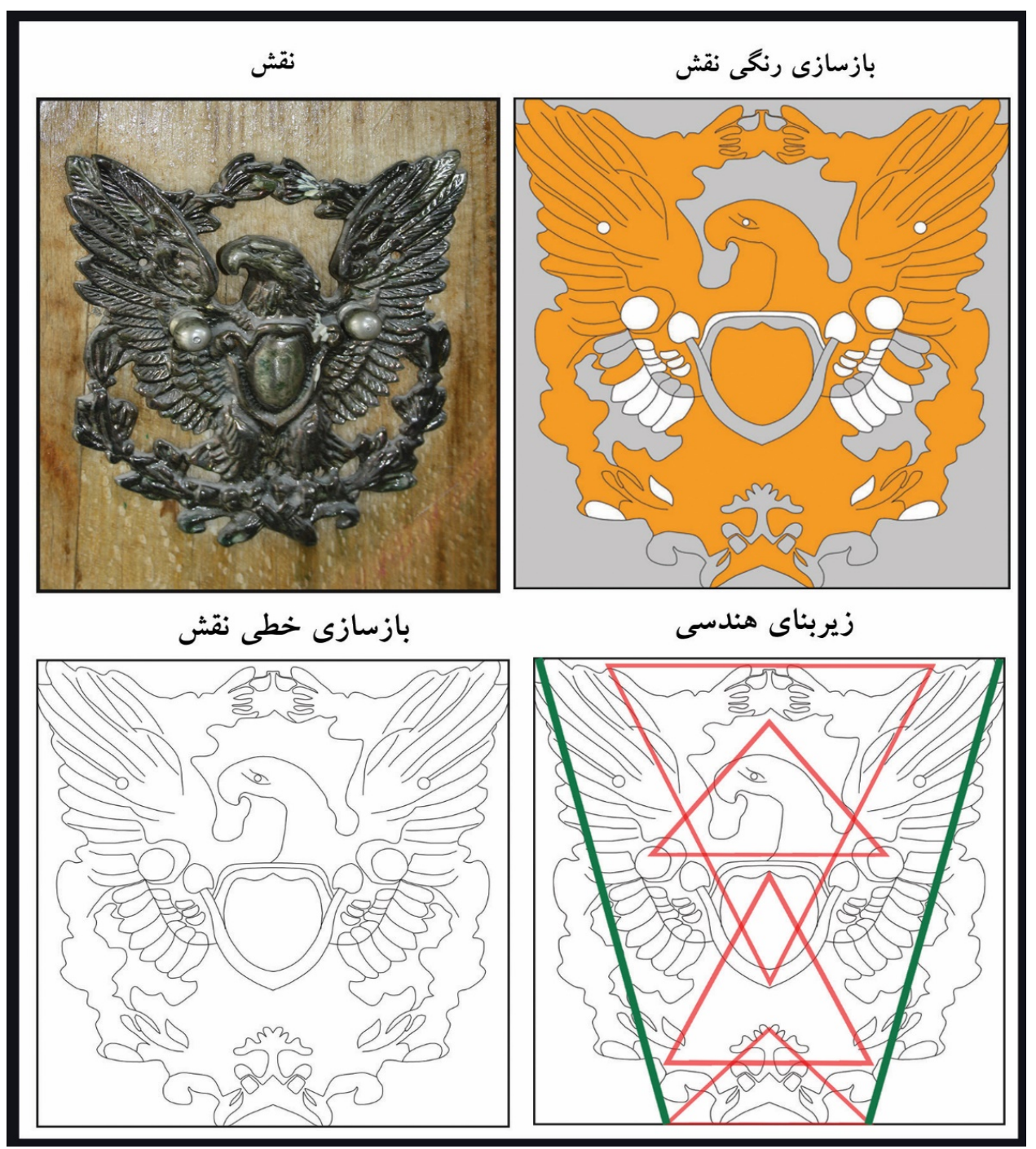


Figure6-. The role of the Holy Abdullah Obeidullah (AS) Damavand, reconstruction and infrastructure of linear and geometric color; Source: authors

By order of "Cyrus the Great", the blue fabric with a design of gold (gold) of the imperial eagle (hawk), the Persian Empire was used as a symbol of authority and army flags. In this site in honor of "Cyrus the Great", the theme of the blue and golden eagle in honor of his flag was once the Iranian flag .The Eagle silver (silver) is used as a symbol and logo. (Www.laylazi.ir) In every period of history, Prey birdswere a symbol of strength and speed. . Prey animalsmark suggests that a treasure exists there. Here the eagles view is on the entrance on right side of the door opening and eagle eyes is to pathway of shrine that shows there is a treasure and leads us to the Shrineand the entrance on the left path is towards the exit .BeingOpen the wings of the eagle is sign of a mausoleum that was built in memory of that person. (Www.irantreasure.net)It seems that image of eagle represents the Holy Guardian. (Www.rasekhoon.net) .It is a sign of strength and a symbol of divine protection and the patron god, tall and excellence. (Agriculture, 1389: 99)."Hawk is a bird nest long Stowe, stupid, look sharp, sharp cry, cry thick, thick tip and hard to grip with long life and glory ended in the ability of birds and fowl in the Persianis called "Aleh (s)."(Dadvar and Mansoori, 1385: 111)The eagle means knowledge, freedom, hope, faith, authority, divinity, patience, fearlessness, purity, fertility, lightning, divine power, the power of flight and moving. (Habibi, 1381: 120)The eagleinside a ringthat is a sign of respect to the covenant.The ring, which is alinear circle, indicates that we begin from each point we will get back to the same point.This means that every action and deedsWill happen in this life (the circle)The resultand its impactwill remain in the man's world. (Open to reach the area of the circle) and other mental world of reward or punishment will be enjoyed.

\section{HUMAN PAINTINGS}

This category of books that portray human beings in different states pay Since the beginning of the tradition was of their attention. The motifs inscribed on the walls of caves of Lorestan and Kun Khwaja the Parthian period and contemporary paintings, paintings can be traced to a human of all types of Persian arts, Human imagins especially in the Achaemenid and Sassanid periods that the Iranian art was the royal art. And the image of the king in various states dealt with, were highly regarded. But in the Islamic era, the art of creating an atmosphere that helped mankind in its eternal path of knowledge.Avoids everything can be even partially and temporary idols. (Burckhardt, 1370: 16Z). That is why the human figure loses its importance. But despite the limitations of imaging, they still continued to exist. Although architectural motifs and decorations were marginal, imaging, scientific treatises, stories and epics were used. Restrictions of Muslim religious beliefs and caused it not to work and develop their designs Shrine and overall scope of the relief in the shrine was zero.

\section{PICTOGRAPHS}

Albhnsy the decorative motifs in Islamic art, said: "This phenomenon interesting art is not a simple role, but of the kingdom and the might of God, and at the same time a religious verse and the verse of art. What we see in these roles is in fact an interpretation of worshiping but for invention. " (Albhnsy, 1385: 121Z). In general, one of the ways to decorate artwork or description of what it means to be used to complete the inscription journalists. Throughout history inscriptions have been used in three ways: 1 To transfer messages or record specific events and narration as well as public service announcements; 2. To show the specifications and the manufacturer's name and logo or artwork or client And in a kind of sign; 3. In order to emboss the building or work of art and Quranic verses informative sentences with the aim of reverence and sanctity More from this group Islamic religious works has been welcomed by many. (Sheriff, 1388: 9) Dictionaries, have meaning scroll to the hands of the army or the army or the herd of horses. When the inscription to be carefully observed in accordance with the literal meaning is revealed, Because the letters can be seen as a cavalry parade .Various positions of heads remember swords and spears and flags . Writing any line of Islamic lines for inscription is possible. (Fazaeli, 1376: 130) 
Table3. The results of the distribution relief in the Holy Abdullah Obeidullah (AS) of Damavand. Source: authors

\begin{tabular}{|r|r|r|r|r|r|r|r|r|r|r}
\hline Percentage & $\begin{array}{r}\text { The } \\
\text { number } \\
\text { of } \\
\text { motifs }\end{array}$ & Sanctuary & $\begin{array}{r}\text { External } \\
\text { wall }\end{array}$ & $\begin{array}{r}\text { Interior } \\
\text { wall }\end{array}$ & Column & Roof & Window & Door & shrine & $\begin{array}{r}\text { Placement } \\
\text { locations } \\
\text { and designs }\end{array}$ \\
\hline $53 \%$ & 9 & & 5 & & & & & 2 & 2 & $\begin{array}{r}\text { Geometric } \\
\text { patterns }\end{array}$ \\
\hline $6 \%$ & 1 & & & & & & & 1 & & $\begin{array}{r}\text { Animal } \\
\text { motifs }\end{array}$ \\
\hline $29 \%$ & 5 & & 1 & & & 1 & & 1 & 2 & $\begin{array}{r}\text { Plant } \\
\text { designs }\end{array}$ \\
\hline $12 \%$ & 2 & & & & & & & & 2 & Pictographs \\
\hline $100 \%$ & 17 & & 6 & & & 1 & & 4 & 6 & $\begin{array}{r}\text { The } \\
\text { number } \\
\text { of }\end{array}$ \\
& & & & & & & & & &
\end{tabular}

According to a survey designs in Imamzadeh Abdullah Obeidullah (AS), which includes 17 roles, in order of frequency and percentages is as follows: Geometric motifs: 9 and 53\%; plant designs: 5 and 29\%; pictographs: 2 and 12\%; animal motifs: 1 x 6\%. (Table 3 and Figure 1).

$$
\text { घeometric moti } \quad \text { animal motif } \quad \text { plant motif } \quad \text { pictograph }
$$

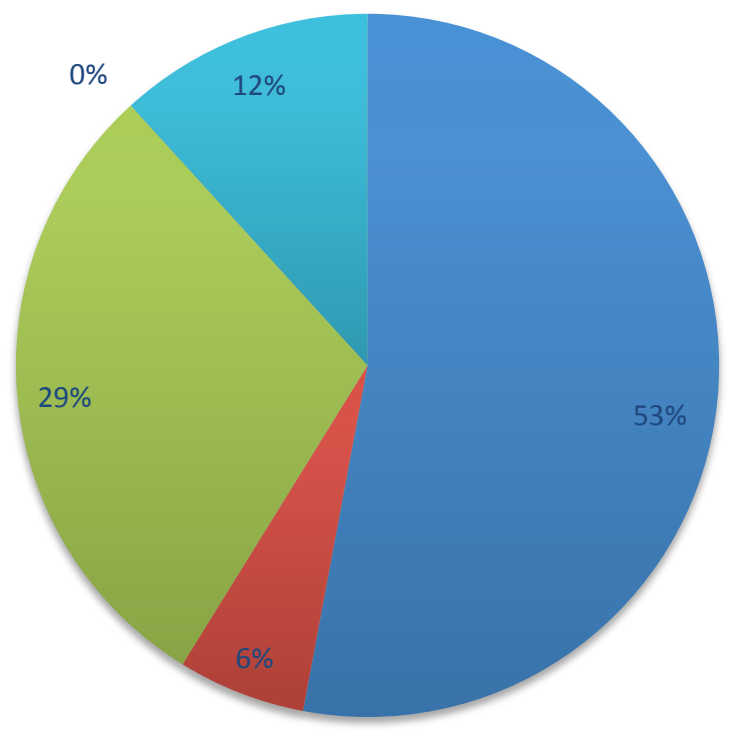

chart 1: Distribution of frequency and percentage search results motifs Shrine of Damavand city Divided by subject Source: authors

Table 4. Percentage distribution of relief Amamzadhhay search results based on the classification issue and components based in Damavand city. Source: authors.

\begin{tabular}{|l|l|l|l|l|l|l|l|}
\hline Percent of & The total & pictogr & plant & animal & Geomet & The components & رديف \\
\hline
\end{tabular}


The Turkish Online Journal of Design, Art and Communication - TOJDAC August 2016 Special Edition

\begin{tabular}{|c|c|c|c|c|c|c|c|}
\hline $\begin{array}{r}\text { all } \\
\text { componen } \\
t \text { designs }\end{array}$ & $\begin{array}{r}\text { number of } \\
\text { each of the } \\
\text { component } \\
\mathrm{s}\end{array}$ & aphs & designs & motifs & $\begin{array}{r}\text { ric } \\
\text { motifs }\end{array}$ & & \\
\hline $37 \%$ & 89 & 18 & 47 & & 24 & Shrine & 1 \\
\hline $25 \%$ & 60 & 2 & 38 & 1 & 19 & Door & 2 \\
\hline $8 \%$ & 20 & & 4 & & 16 & Window & 3 \\
\hline $9 \%$ & 23 & & 7 & 1 & 15 & Roof & 4 \\
\hline $1 \%$ & 3 & & 3 & & & Column & 5 \\
\hline $12 \%$ & 29 & 3 & 15 & & 11 & Interior wall & 6 \\
\hline $6 \%$ & 15 & 5 & 2 & & 8 & External wall & 7 \\
\hline \multirow[t]{2}{*}{$2 \%$} & 4 & 3 & 1 & & & Sanctuary & 8 \\
\hline & 243 & 31 & 117 & 2 & 93 & $\begin{array}{l}\text { The total number of } \\
\text { each of the } \\
\text { components }\end{array}$ & 9 \\
\hline $100 \%$ & & $13 \%$ & $48 \%$ & $1 \%$ & $38 \%$ & $\begin{array}{l}\text { Percent of all of the } \\
\text { components }\end{array}$ & 10 \\
\hline
\end{tabular}

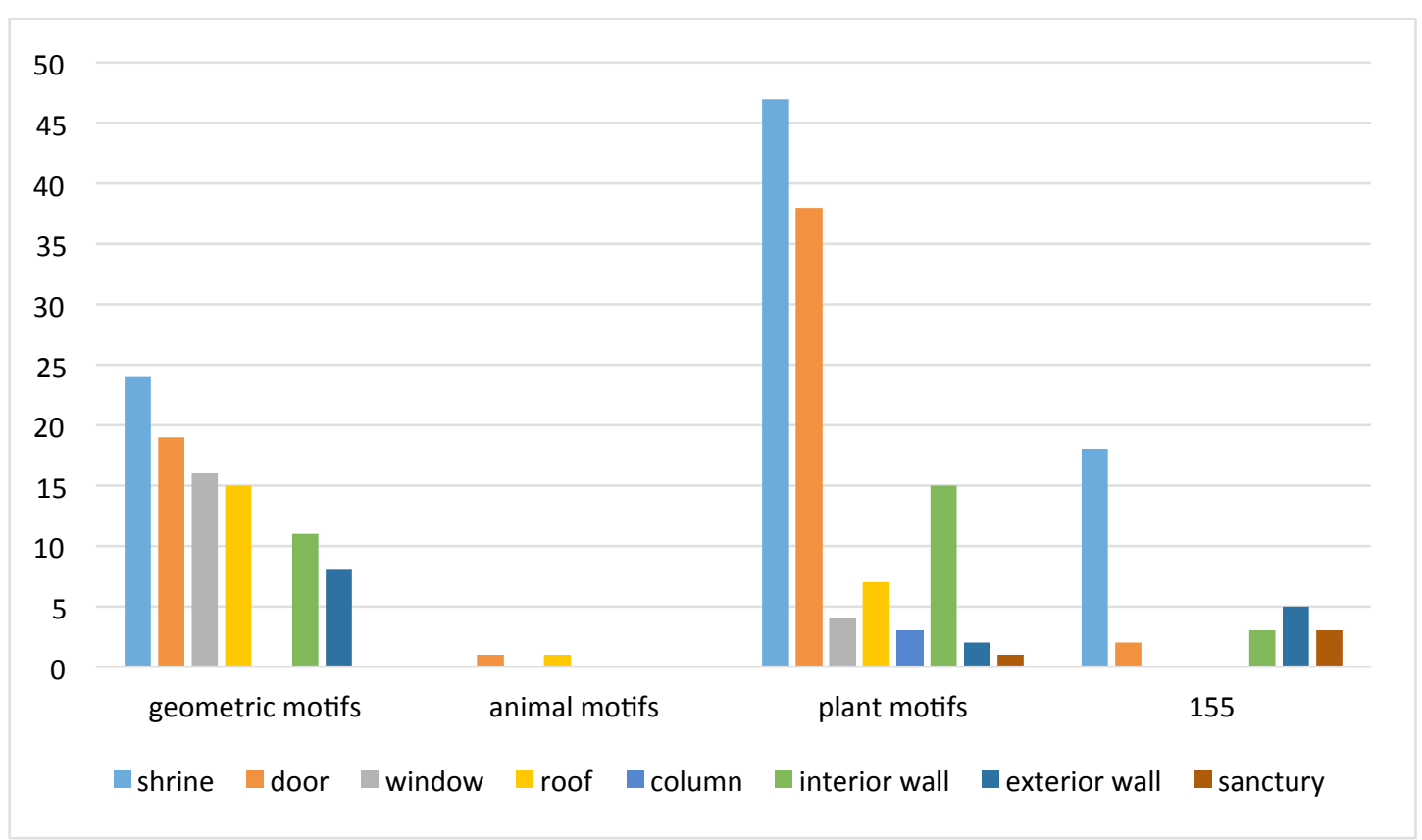

chart2: Frequency distribution and percentage of survey results Imamzadeh Abdullah Obaidullah Damavand based division of thematic motifs Source: authors 


$$
\text { geometric motifs } \square \text { animal motifs } \square \text { plant motifs } \quad \text { pictograph }
$$

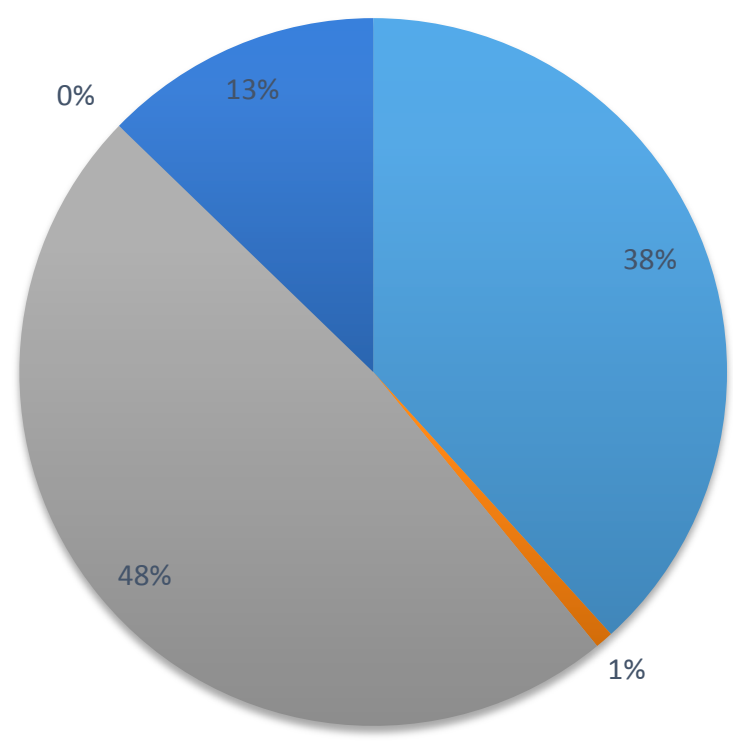

chart3: Distribution of books search results in the Shrine of components based in Damavand city Source: authors

whrine $\square$ door $\square$ window $\square$ roof $\square$ column $\square$ interior wall $\square$ exterior wall $\square$ sanctury

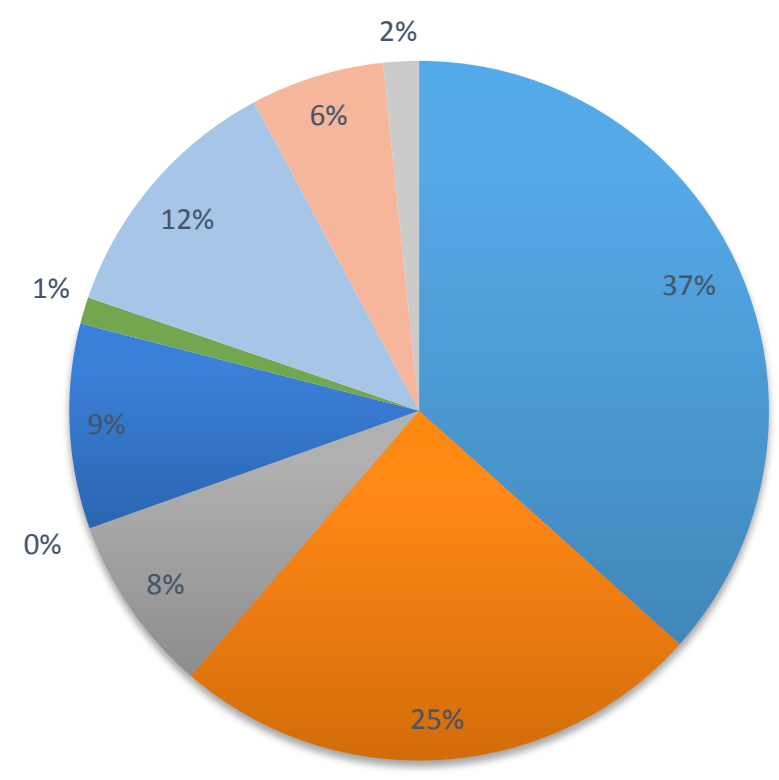

Chart4: Distribution of frequency and percentage search results motifs Shrine of Damavand city Divided by subject Source: authors 


\section{CONCLUSION}

Non-material and spiritual topics are non-visual and performing., And because there are real issues and facts,to show them have to used a means of initiating the most obvious and most common among the different communities is "symbol". Any society, especially religious-spiritual communities, requires familiarity with the secrets and symbols are common and common in our culture and society, To their community and their cultural relation with literary and artistic works and has established a fuller and better understanding of these effects may be provided.Alienation communities with their cultural heritage is one of the issues that afflict many societies in recent decades, It is natural that the purpose of the recognition and protection of cultural heritage, are not focusing solely on material aspects and some;But what is important is to recognize outstanding aspects of qualitative and spiritual attributes and characteristics and particular features, Thinking and find waysis to use and take advantage of them in their life today.Due to erosion every day and works by taking the value of the works, both from a physical and symbolic aspects,is requiredto study more deeply about them .Because these designs are part of the land art treasuresand knowing them helps to sustain relief. Iranian-Islamic motifs that is full of mystery and parcel of kindness is the fruit of labor.With love, frenzy and his efforts during the past centuries marked on the page of time.Understanding the mysterious motifs of Islamic Iran as a special contribution in the development and promotion of fundamental motor armature can open new perspectives in the field of graphic artists .According to the research the following results:1.divisions thematic motifs based in Damavand city Amamzadhhay divided into 4 categories:

1) plant designs 2) geometric 3) pictographs 4) animal motifs

2. symbolism and motifs continuityhas always during different historical periods of the features and Islamic Iranian art .

3. The tool displays immaterial and spiritual topics, sign and symbol.

4. motifs and decorative designs clarifying the facts and realities of the Islamic world

5. Holy designsare based on Iranian culture - Islamic world to create material and spiritual link

6. Nature does not imitate the humility of the artist since the establishment of God's own perfection

7. According to a survey designs in Imamzadeh Abdullah Obeidullah (AS) which contains 13 signs

8.As frequencies and percentages is as follows: geometric motifs: 53 numbers and $9 \%$; vegetable motifs: 5 and 29\%; motifs of pictographs: 2 and 12\%; animal motifs: 1 And 6\%. Is the Most designs and the outer wall of the shrine doors each with 6 role. (Table 3 and Figure 1 )

9. According to the survey Amamzadhhay motifs in the city of Damavand, in order of frequency and percentages is as follows: : Plant designs: 117 x 48\%; geometric motifs: 93 and 38\%; motifs of pictographs: 31 and 13\%; animal motifs: 2 and 1\%. (Table 4 and Figure 3)

10. According to the designs of the components Amamzadhhay the city of Damavand Most motifs in the shrine with the plant designs with 47 to $37 \%$ is used. (Table 4, Figure 2 and Figure 4)

\section{REFERENCES}

\section{Book:}

Askndrpvr joy, Smith (1383), Art and shows, Tehran, Ministry of Culture and Islamic Guidance.

Albhnsy, Afif (1385), Islamic art, translated by Mahmoud Pourghassem, Tehran, Navideshahed.

Titus Burckhardt (1370), Islamic art, language and speech, translated by M. Rjbnya, Tehran, Soroush.

Habibi, H. (1389). Some of the tomb, the tomb and the tombs Tehran and Albrz.jld, printed, Tehran, Iranian Studies Foundation.

Dadvar, A. and E. Mansouri (1385), An introduction to the myths and symbols of Iran and India in ancient times, first edition, Tehran, Kalhor University, and publications.

Said, Edward, Islam, media, translation: Akbar officer, Tehran, publishing Birch, 1379.

Fazaeli, Habibullah (1350), Atlas line, Isfahan, Isfahan National Monuments Council. 
Agriculture, M., and M. Ahmadi Sheikhani (1389), geometric motifs. second edition. Tehran: culture Saba.

Gilani, Sayyid Razi (1393), media and Islamic Art, Qom, Islamic Republic of Iran Broadcasting (IRIB), the Islamic Research Center.

Snacks, Nahytav Vahide Myrfkhrayy (1393), geometry designs, printing, Tehran, Fkhrkya.

Najafi, Ayatollah Zia (1390), Amamzadhhay Iran, printing, Tehran and Qom, publications Ahl alBayt (AS).

Halen Brand, Robert, Islamic art and architecture, translation: Ardeshir illuminated, Tehran, Academy of Arts and publication of Aperture, 1378.

\section{Article}

Khakbaz Alvndyan, E. and M. Science (1391), "arrays for the monument Sydrknaldyn (School Rknyh) Yazd, a masterpiece of art and religious architecture of Muzaffarids" The Journal of Islamic Art Studies, Issue 17, pp. 45-60.

Nadim, F. (1386), "Take the decorative motifs in Iranian art," Art Journal, Volume IV, Issue 4, Page 17.

Neiestani, J. and Meysam Lyny (1392), "Study of inscriptions on the tombs of fund some Lavasanat area and QasranRudbar" The Journal of Islamic Art Studies, Issue 18, pp. 47-63.

Hzavhay, H. (1363), "Slim, forgotten language", Journal of Art, (6).

\section{Thesis}

Sheriff, A. (1388). "Checking the contents of Shia religious buildings Mazandaran until the end of the Qajar", MSc thesis research, art, H. Ayatollahi, Shahed University.

Centurion, AS. (1394), "pictorial semiotics designs Amamzadhhay city of Damavand Tehran Province", MSc thesis Artbattsvyry, Syed Nizamuddin Amamyfr, Shahed University.

\section{the site}

http://ehonari.blogfa.com/1392/07/2

www.irandeserts.com

www.irantreasure.ne

www.laylazi.i

www.rasekhoon.net

http://rclit.ir/Default.aspx?tabid=5981

\section{Latin resources}

Ananda Coomaraswamy, (1977), Traditional Art and Symbolism, Ed Roger Lipsey, Princeton University Press. United State, P. 330.

Dalu Jones, "The Elements Of Decoration: Surface, Pattern and Light", PP 161- 163.

Frithjof Schuon, (1963), Understanding Islam, Foreword by Annemarie Schimmel, Wirld Wisdom, United States, P. 180. 